\title{
AN ANALYSIS OF HOUSING LOCATION ATTRIBUTES IN THE INNER CITY OF BUDAPEST, HUNGARY, USING EXPERT JUDGEMENTS
}

\author{
Tom KAUKO \\ Department of Geography, Norwegian University of Sciences and Technology, NTNU, \\ Trondheim, Norway and OTB Research Institute for Housing, Urban and Mobility Studies, \\ Delft University of Technology, Delft, The Netherlands \\ Tel.: +47 73591919; fax: +47 73591878; E-mail: tom.kauko@svt.ntnu.no
}

Received 10 August 2007; accepted 12 October 2007

\begin{abstract}
The role of location quality in housing consumption is an increasingly important research objective given the demand-side considerations stemming from economic and sociocultural changes in urban and metropolitan housing market areas. In circumstances involving diversified demand, the consumption pattern comprises a set of different preference profiles. From an operational point of view, such outcome can be generated through ranking location attributes with respect to their relative importance for the house buyer or renter. This procedure may, for example, be based on pair-wise comparison of attributes based on expert judgements and the analytic hierarchy process (AHP). This study is based on expert elicited residential location quality profiles in the inner city of Budapest, and builds on prior work on housing market analysis reported elsewhere. Here the particular issue, typical for post-communist circumstances, concerns a mismatch between the range of available product groups and the increasingly quality conscious and differentiated buyer preferences.
\end{abstract}

KEYWORDS: Analytic hierarchy process (AHP); Budapest; Expert judgements; Housing consumption; Inner city

\section{INTRODUCTION}

The role of location quality in housing consumption is an increasingly important research objective given the demand-side considerations stemming from economic and socio-cultural changes in urban and metropolitan housing market areas. The reason for this growing importance is that we are experiencing a shift from a suppliers market towards buyers market, where diverse branding strategies and lifestyle segmentation are becoming crucial for builders and developers as well as planners and policymakers, in order to know what the housing consumers want in terms of the dwelling and environment characteristics. In circumstances involving diversified demand, the consumption pattern comprises a set of different preference profiles. From an operational point of view, such outcome can be generated through ranking location attributes with respect to their relative importance for the house buyer or renter. This procedure may, for example, be based on pair-wise comparison of attributes

International Journal of Strategic Property Management

ISSN 1648-715X print / ISSN 1648-9179 online (C) 2007 Vilnius Gediminas Technical University http://www.ijspm.vgtu.lt 
based on expert judgements and the analytic hierarchy process (AHP). While not sufficiently robust in itself, this information is suitable to enhance the housing market analysis by confirming and animating the findings obtained by larger scale models based on market data or questionnaire surveys.

In this paper I report findings concerning housing consumption in the inner city of Budapest, Hungary. For this selected supply side segment, one aggregate model and a few disaggregated models (i.e. demand sided segments) of preference profiles were generated based on expert judgements and the AHP. The originality of this contribution lies in the application of unconstrained (i.e. ex ante) choice modelling for CEE/post-communist housing circumstances. Here two interlinked issues stand out: one, the quality of locations (with a bottom up definition of the unit of analysis, i.e. neighbourhood or vicinity); and two, the specificity of a local market context that suffers from mismatch between supply and demand. The study has two aims related to these two issues: first, to assess the determinants of intra-urban housing location attractiveness using the AHP tool; and second, to understand the contextual factors behind the resulting assessments. In a broader sense, this research project involves triangulation in order to confirm and to animate the findings obtained from prior housing market analysis of Budapest based on market data (Kauko, 2007), as well as comparison with findings from comparable studies from other housing market circumstances.

Section 2 describes some intricacies within the study area that ought to be taken into account when designing the research. Section 3 reviews the literature on expert interviewing and the AHP technique, in order to position the study. Section 4 presents the analysis of descriptive material, interviews and the AHP exercise. Finally, section 5 concludes the study.

\section{HOUSING SUBMARKETS AND RESIDENTIAL PATTERNS IN BUDAPEST}

It is argued that Eastern European countries are of general interest due to the dramatic changes made from communist-type welfare systems to a free market system (Kovács, 1997; Kovács and Székely, 2004). As a result of the social and economic changes, residential segregation patterns have emerged (Kovács, 1998). According to Kovács (1994), in Budapest the basic ecological structure coincides with the physical geographic features: high status areas are traditionally situated near the River Danube and in the hilly Buda side in the west and in the centre of the city, with concentrations of low-income households at the outskirts of the city (see Figure 1). The mean price levels in the prestigious Buda side districts II and XII were already by the early 1990s three and a half times higher than the mean price levels of the working-class areas of Pest (Kovács, 1994).

While segregation of social groups existed in Budapest and other socialist cities, and that this was also measurable on the spatial level across neighbourhoods, it may be argued that the early 1990s privatization contributed further to the increasing spatial differences (see Kok and Kovács, 1999). After the year 2000 the Hungarian right-centre coalition government launched a programme for the construction of new public rentals, but its impact was/ is negligible in Budapest where the liberals and socialists are in power. To balance the lack of social housing programs a new mortgage system that improved the affordability of homeownership for middle-income starter households (in particular, with respect to the larger dwellings) was launched in the year 2000 , but this system lasted only two years to the next parliamentary elections. On the other hand, piecemeal redevelopment of inner city sites and luxurious housing construction 
(residential parks) in certain locations for the most affluent buyers has indeed occurred, and it is predicted that middle-class buyers, too, will be targeted for high quality houses or apartments. Continuing the urban renewal further will however be increasingly difficult due to predominantly private homeownership. This impediment to rehabilitation and renewal might however be overcome with a well organised condominium board.
The prestige of the neighbourhood is another factor that influences market driven urban renewal. Kovács and Wiessner (2004) noted that the restructuring of the Budapest housing market is a spatial matter: areas are differentiated in terms of price levels and social standing. While Kovács and Wiessner recognise problems in the inner city and the most monotonous housing estates that need to be addressed by urban policies, they nevertheless

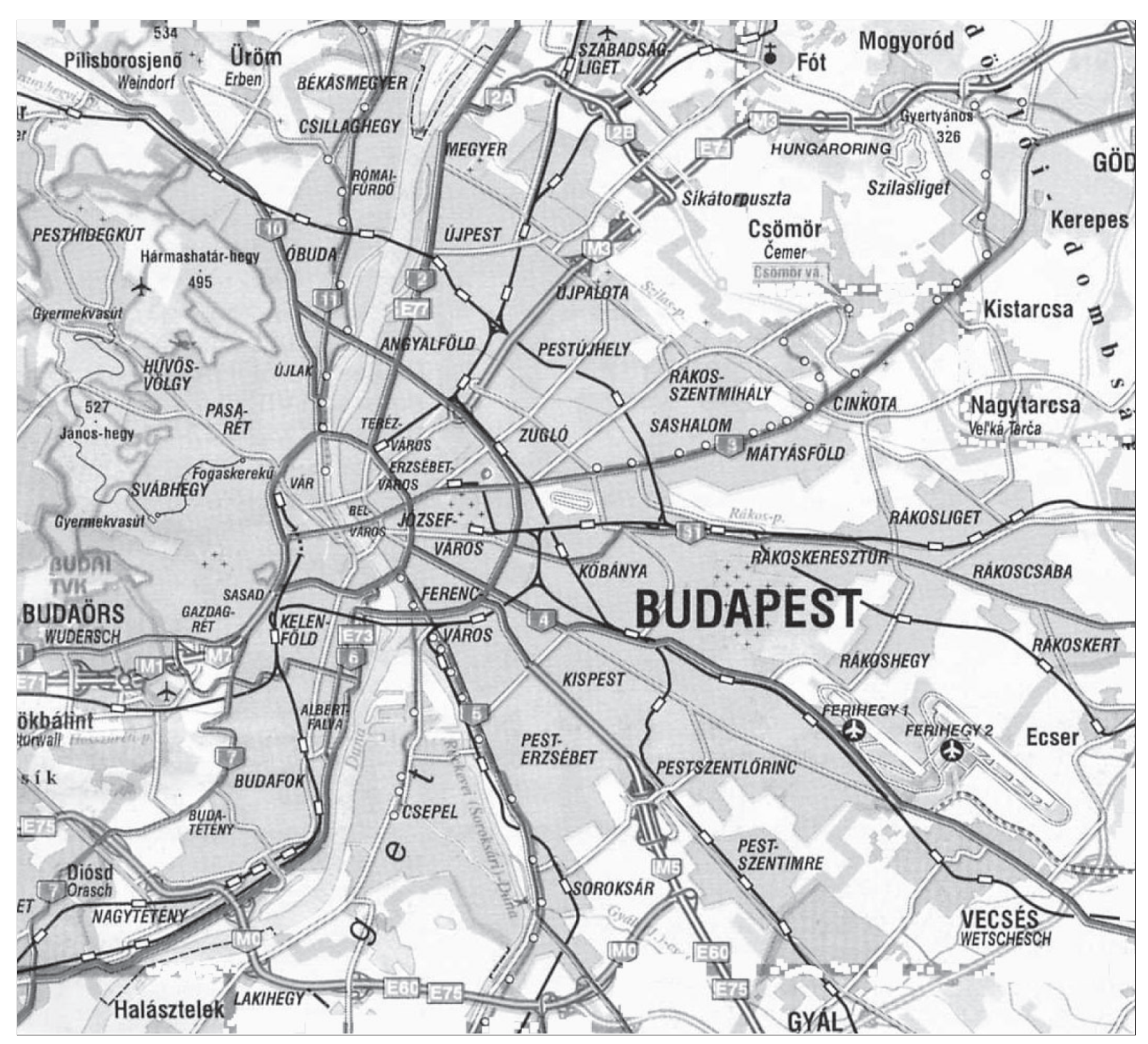

Figure 1. Map of Budapest 
offer optimistic prognoses for the city as a whole. A notable new feature is the development of 'residential parks' from 1999 onwards - these are modern, guarded condominium buildings of two to three times higher market price than the average (Kovács and Wiessner, 2004).

In the 1980s the worst types of housing micro-locations in Budapest were the tenement buildings situated in the inner city along the Grand Boulevard, and just outside it. Two decades later, these types of dwellings and housing environments still remain at the bottom of the market. On the other hand, about one third of the housing stock in Budapest is prefabricated high-rise. There are differences in the prestige of the building types, and these differences coincide with the era in which they were built (see Egedy, 2000, 2001; Kovács and Douglas, 2004):

- 1950 s and early 1960s: the 'Stalin baroque' or 'social realism' style, comprising small blocks of low density; these are traditional buildings adjusted to the urban environment.

- Late 1960s: the first prefab projects, comprising still relatively small, lowrise blocks without elevator or central heating, often surrounded by open space; these were allocated based on merit.

- 1970s: the Soviet-style, high-rise giant estates with 5,000-15,000 flats, lift and central heating, often built in peripheral locations with poor infrastructure; the welfare aspect in their allocation caused stigma and today these are the most problematic estates.

- 1980s: better quality housing estates.

According to Bertaud (2006) in general CEE cities have 'European' characteristics: a strong and prestigious inner city, served by functioning public transport system, and today these characteristics are being re-evaluated by the market. At the same time, these cities have typically post-communist characteristics too; because the urban form did not follow prices, today the density gradient is lagging the price gradient, which, given mono-centricity, manifests itself in a derelict industrial zone too close to $\mathrm{CBD}$, a lack of retail and service space in city centers, and residential estates built at the outskirts of town. Therefore, one ought to pay attention to the particular local market context and its path of development, rather than assume that market evidence is completely transportable from Western to more Eastern settings.

The mismatch between available product groups on offer and the aspirations of the consumers is a problem of the inner city housing market in Budapest like in other post-communist cities. Due to historical reasons the inner city housing stock, particularly on the Pest side of the river Danube, suffers from deterioration and monotony. At the same time the increasingly quality conscious and differentiated buyer preferences of the growing middle and higher income groups are not recognised to a sufficient extent.

The following section develops a methodology for market analysis of housing choice in a post-communist/CEE context. This methodology is based on the AHP tool and expert judgements, Despite the mismatch problem noted above the existence of relatively unconstrained market-based preferences for certain neighbourhood qualities is assumed. It is not to say that the same methodology is not suitable for more Western market circumstances, as the conceptual ideas much are building on the extensive literature that theorizes market segmentation, going back to pioneering work by Grigsby (1963) and numerous authors since, who mainly have looked at North American and British cities. In this work it was recognised that the housing market in one and the same urban area is segmented into different, 
often spatial submarkets, each with a specific mix of dynamic and static features that determine the composition of supply, demand and/ or price. As a consequence, visible or invisible boundaries prevail and emerge between locations that, for one reason or another, are not substitutes for each other (see e.g. Maclennan, 1977; Grigsby et al., 1987; Rothenberg et al., 1991; Whitehead, 1999).

\section{THE EXPERT INTERVIEWS AND PREFERENCE MODELLING APPROACHES TO LAND USE AND HOUSING MARKET ANALYSIS}

\subsection{Modelling stated choice}

Sophisticated consumer choice modelling methodologies have been proposed, inter alia, by Di Clemente and Hantula (2003) and Guerin (2003). Methods based on stated (as opposed to revealed) choices allow us to identify consumer choice empirically using semistructured interviews. Within this tradition of housing research known as perceptions/preferences modelling, many other specific methodological issues have gained attention too, such as group decision-making (Molin et al., 1999), neighbourhood aspect (Galster, 2001), how to incorporate supply side shortages (Rietveld and Wagtendonk, 2004), and transitional housing markets (Wang and Li, 2004). Multidimensional decision analysis techniques comprise a sophisticated tool for land use related or environmental problems that require behavioural or prescriptive treatments (see Gregory et al., 1997). While this genre fits well into the housing consumption and preference modelling tradition, it eschews the more philosophical debates within economic theory and methodology that tend to be attached to the use of stated choice methods. A related multicriteria decision making methodology has been applied for the determination of the utility de- gree and market value of real estate using experts' assessments of preference decisions on competing alternatives (see Kaklauskas et al., 2007).

Multidimensional value and benefit refers to a generic quality measure that goes beyond monetary value or transaction price (Gregory, 2000). According to this modelling tradition the elicited preference models are suited for making monetary values (i.e. market prices) commensurable with non-monetary (i.e. environmental, social, cultural, aesthetic, ecological etc.) values, for various locations or housing bundles (Kauko, 2002, 2003, 2006). In a related strand of inquiry, Daly and colleagues (2003) advocate the 'behavioural paradigm' in residential valuation, which puts more emphasis on the demand or consumer-driven factors related to preferences and intangible quality components.

\subsection{The AHP and expert judgments}

The analytic hierarchy process (AHP, Saaty 1977) technique is based on pair-wise comparison of elements (attributes or alternatives). In sharp contrast to the classical multi-attribute value-tree modelling approach, which is based on the assumption that utility functions can be explained, the AHP does not assume that the evaluator is able to express the overall elicitation of the problem as a single function. Instead, the AHP is based on the assumption that the relevant dominance of one attribute over another can be measured with a systematic, pair-wise comparison (e.g., Ball and Srinivasan, 1994). This elicitation of weights for the elements under comparison takes place in two stages: initially as ordinal ranks using the original scale of the input, and eventually cardinally as ratios between 0 and 1 derived via a matrix comparison of the ordinal ranks. (See Kauko, 2004, for full explanation).

In other words, the AHP requires numerical ordinal data and measured facts. The com- 
parison begins at the lowest level, where the elements (attributes or alternatives) are usually elicited with an ordinal scale from 1 to 9 , with the values corresponding to verbal expressions. A value of 1 means that 'both are of equal importance', and a value of 9 means that ' $A$ has an extreme importance over B'. The comparisons are then converted into cardinal rankings. Balancing the pair-wise ranks in this way involves the use of measurement theory, as pair-wise judgments cannot be assumed consistent across the entire set of comparisons (e.g., Ball and Srinivasan, 1994). Finally, local weights are transformed into global weights. The most attractive choice is determined by aggregating the local priorities into global priorities. These procedures generate a value tree model, where the overall objective of the decision stands at the top of the hierarchy, with lower-level objectives or attributes at the lower levels (e.g., Zahedi 1986).

Methods such as the AHP have an added value in situations, when more nuanced insight into the context is needed. For this we need different variables than the ones readily available in registers, and as a consequence, a different way of collect the data - through interviews. Given that the method was developed by psychologists, and that it is often used on a set of less than ten attributes or cases, the problem is that is not suited for comparison of several observations simultaneously. Moreover, in order to cover all relevant interest groups, the set of respondents have to be selected meaningfully, not random. Hence the method of saturation is preferred instead of statistical sampling (see Pöyhönen, 1998). Using this method each new respondent is expected to contribute with new information, and if that is not the case, including a new respondent does not bring added value that would offset the time costs involved in the interviewing. This implies that the number of respondents does not have to be high - depending on the application even one expert may be sufficient, because, rather than relying on statistical sampling, the use of AHP is always depending on qualitative information relating to the defined context as well as order and scale of variable levels (Kauko, 2002).

The AHP has already been applied successfully in various contexts with different aims and objectives, data size and merits. In a classic demonstration Saaty (1990) showed how to select the best (single-family) house to buy for one (hypothetical) decision maker. In a similar setting, Ball and Srinivasan (1994) offered a rigorous evaluation on the use of AHP, and an application of the role of psychological factors in house selection (again one decision maker) in a suburb of Boston, US (see also Ong and Chew, 1996). Prior studies show that the optimal size of selected respondents for the AHP when used for housing quality and area assessment is about twenty (Nevalainen et al., 1990; but see also Bender et al., 1997, 1999, for the use of questionnaire survey). Most recently, the AHP has been applied for land mass appraisal in Donetsk, Ukraine by Kryvobokov (2005, 2006). In the realm of environmental externality related economic impact analysis AHP has been applied by Erkut and Moran (1991). Using related methodology, impact analysis has been conducted by Willis and Garrod (1993), McLean and Mundy (1998), and Strand and Vågnes (2001).

While the AHP fundamentally is not meant as a statistical survey method, the attribute weights elicited by the AHP can be understood as weights in housing market models, for example, as hedonic coefficients. It is however acknowledged that the experts may underestimate the intensity of the effects of each attribute compared to market participants (i.e. averaging). Kryvobokov (2006) compared the outcome of expert and market based methods by relating each resulting attribute weight or hedonic coefficient to the sum of all weights (or hedonic coefficients) in the model. This exercise showed that the weights resulting from 
the AHP and also those resulting from a direct questionnaire have systematically lower field ranges than the corresponding hedonic regression coefficients. In other words, the least important attributes were overvalued, and the most important attributes undervalued by the expert based models in relation to hedonic models.

On the other hand, existing market data may be an inappropriate mirror of market reality, in which case interviews become apt. When the equilibrium pertains to choices - not prices - the focus tends to switch to preferences and intangible quality features, and then the measured values can be all kinds of values - not just monetary ones. This way seen the method has two obvious and substantial benefits: (1) it allows for diversification of demand (and then indirectly also supply); (2) it ascertains an intangible elements in relation to perceptions (see Kauko, 2004). The method has certain problems however, such as the inevitable lack of robustness, the inherent property of the AHP restricts the elements to compare to very few, and the inability to perform direct comparison of validity with results obtained with methods based on revealed choice and market outcome data.

Lastly, each of the preference profiles is compared with known cases based on earlier research, but possibly from other circumstances. In this way the findings of the AHP together with prior information can be used for building an operational typology that covers the phenomenon, in this case location-specific housing consumption, as broadly as possibly. This methodology, referred to as naturalistic generalisation, implies that, rather than assuming any strategic reason for generating typical cases, the case repertoire is growing with each new result, with the eventual purpose in operational classification (see Johansson, 2005).

\section{SEMI-STRUCTURED INTERVIEWS USING THE AHP}

\subsection{The study area}

The Budapest inner city can be considered a special case, when relating the study to more Western type of housing market circumstances. Here the starting point is to note that in $\mathrm{Bu}-$ dapest a Western style suburbia is yet to develop. While there are a lot of settlements around Budapest that grew very intensively after 1990 and a massive suburbanisation process took place, this suburbanisation process is showing signs of slowing down as the public transport system capacity is lagging behind still ca. $60 \%$ of the transport within Budapest is public (Tosics, 2006). After the 1990s period of beginning suburbanisation, today two trends work against urban sprawl as Locsmandi (2006) notes: (1) the private housing boom within the city; (2) the lack of public investments in transportation facilities. On the other hand, in the inner city urban renewal and housing rehabilitation has been on the agenda constantly for the last twenty years. This is because the inner city area comprises a big problem for the whole image of the city - an increasingly important urban policy aspect. The housing market balance between supply and demand is not well developed after the socialist era as the existing stock is to a great extent derelict, especially with respect to the maintenance of communal areas and the facades, and lagging behind the preferences of those consumers with purchase power. As already noted, on a detailed level the situation is indeed very different than in the Western urban context. On a more general level, it is possible to nevertheless make some cautious links to certain contested urban and neighbourhood regeneration issues brought up in Western policy evaluation studies (see e.g. Cameron, 2006), in so far as the discussion concerns attracting the targeted population segment nec- 
essary for housing market renewal without neglecting the rights of the current residents.

At the time of interviews (summer 2005) the market for private dwelling construction is very marginal at the citywide level; out of 800,000 units the output of the last ten years is ca $5 \%$, which is the share of those households who are 'in the market'. (This figure has apparently increased somewhat since then, due to the activity of first time buyers and younger up-graders.) Within this group, the target for the analysis reported in this paper is the segment that comprises households who move to the outer part of the Pest inner city, that is to say neighbourhoods in the following Pest-side districts (around the circular Grand Boulevard, clockwise from north to south, see the right hand side of the map in Figure 1):

- Újlipótváros, i.e. the inner part of district XIII situated by the river (best image),

- Terézváros, district VI,

- Erzsébetváros, district VII (VI and VII are small districts, where the government is passive in relation to urban regenerations),

- Józsefváros, district VIII (worst image) and

- Ferencváros, district IX (rehabilitated).

No large differences exist across the microlocations within this 'zone'. (The city-core District $\mathrm{V}$ is here excluded, as it is too luxurious in comparison with the rest of inner Pest.) This area is characterised as transitional zone or potential renewal area. It is assumed that the move takes place from outside this belt.

A number of conclusions could be made from the prior findings from the Budapest housing market (see Kauko, 2007), according to which the spatial housing pattern in relation to price and quality on the micro-locational level is mosaic-like; not just in the poorer area (as suggested by Ladanyi, 1989); but in the whole city's housing market there is a substantial heterogeneity. The type, age and size of the house and its immediate vicinity matter more than the location per se. There is no notable association between price-level and the district location. Even the worst districts possess some relatively attractive places, and also some expensive small dwellings in modern/modernised, non-panel buildings; likewise, even the best districts possess dwellings that are typically cheap because of one reason or another.

The issue of sample size was brought up in the previous section. Nine selected experts agreed to participate in this exercise: a manager of a large developer, a manager of the land management company of one of the district governments, a real estate agent, a real estate consultant, three planning consultants, a statistical officer, and a professor who also worked as a planner. This number is small, largely due to language barriers experienced in this context. The problem was overcome by triangulating the results with other findings of Budapest obtained from the descriptive literature, empirical modelling of Kauko (2007), and in-depth expert interviews.

The first task was to map the relevant differences between micro-locations and recent developments in the study area. The following points were raised in the interviews. To start with, the middle-/upper-middle income groups have more heterogeneous preferences than lower income groups, and as such, very few locations on the Pest side are suitable for them. Whereas Buda is improving, in Pest big pockets are degrading faster than other areas, and the professional middle-class is unable to move out of them. On the other hand, the group of 25-35 years old buy in the inner city after seeing illustrations of refurbished flats in magazines. These projects are reasonably successful.

The Pest side market provides plenty of interesting motives and NIMBY aspects. In 2003 Irish investors invented the market in the districts V, VI, and VII. However, they did not cross 'the lesser Boulevard' (Muzeum körut) to the Palace Quarters, which in fact is a fairly popular neighbourhood among local residents, 
as this area administratively already is part of the infamous VIII district. The image of district VIII is considered bad and worse than the reality. However, this is about the thinking of the people, and this thinking has begun to change. New residents who come from the countryside do not have problem with the image of the district.

On the other hand, even districts with bad reputation (VI, VII, VIII) include smaller parts: i.e. neighbourhoods, that locals know are attractive. These make then good bargains. In particular, district VIII comprises totally different areas: the inner part (Palace quarters), which also is the densest area, is without doubt the most attractive neighbourhood; the Grand Boulevard is the cutting line between the inner and middle parts; the outer parts, including the Clerks quarters, are far away and represent different area types altogether.

Within the mid-Józsefváros there is a diversity of areas in relation to two factors: (1) social status; (2) housing and location quality. New housing development has begun in two of the eleven quarters that the strategic development plan of Józsefváros partitions the whole district (Rév8, 2004). In district VIII no 'real market' has emerged yet, as people are waiting to see how the area will develop. In district VIII the housing prices increased merely because of news - urban renewal and gentrification where about to happen, but the prices were not realised at the market. According to one expert, however, in district IX the reason for high prices are not in social factors, but that of the actions of the first homebuyers, who depend on the availability of subsidies, and the foreign investor-buyers, who are influenced by macroeconomic trends.

\subsection{The attributes}

Given a defined set of attributes, and a set of respondents, the AHP enables profiling the demand side into a certain combination of at- tribute levels. Additionally, more open in-depth interviews were carried out on the same respondents. Below each of the attributes is defined, and after that, the research findings are presented. The findings tell whether, and in what kind of particular circumstances, a given attribute was considered important or not.

Accessibility and proximity: distances to work and services (-) and the level of the public transport system (+).

- This is a 'given'; public transport is good everywhere within the study area: 5 to 10 minutes difference in distances makes no difference, which apparently is typical in Eastern European cities.

- In particular, for the young upper classes, who are mobile, this is not important.

Social factors of the neighbourhood: the socio-economical status (+) and externalities caused by social disturbances (-).

- There may be a large variation within one and the same quarter (as already noted).

- This is worst in the outer parts of district VII and parts of district VIII.

- One comment emphasised the effect of noise, vandalism and other dis-amenities (nuisances), caused by services (see below) that are against residential use.

Service infrastructure in the neighbourhood: availability and level of all kinds of public and private services $(+)$.

- All areas were considered unattractive in this respect - only the big streets have good services.

- Services are good everywhere. (Hence a contradiction with the view above.)

- People are concerned about schools, but they are also mobile (as noted: good public transport) and do not need one in the vicinity.

Physical environment, two types:

1. Hard/tangible factors: density, that is per sq.m. building efficiency. As long as one is situated within approximately 
three to four $\mathrm{km}$ from the city centre, and thereby outside the influence of the repulsion effect of 1970s housing estates which produce a dense and unattractive location on average eight to nine $\mathrm{km}$ from the city centre (see Bertaud, 2006, p. 99), the housing consumers prefer high densities. That is to say, the closer to the Grand Boulevard, the better the location is. Further from the city centre, however, the situation is the opposite as people prefer the suburban single family house.

2. Soft/intangible factors: 'pleasantness', visual factors, greenery etc. are secondary factors. Furthermore, the image implies, among other things, that the particular history of a neighbourhood may be an issue of relevance. By and large, the physical environment is deteriorated in most of this part of town; particularly, it is everywhere in midJózsefváros and Erzsébetváros bad.

Municipality (kerület): whether the municipal image and local government policy, including the social policy and the right to set taxes, matters for the decision. The comments unveil some interesting spatially diversified and conditional effects related to images and policies:
- Young people tend to have higher tolerance for the bad image areas in VIII and VII than older people.

- The policy does not matter so much for ordinary households.

The final comparison was on a higher level in the hierarchy between the composite locational quality, i.e. all the locational attributes above taken together, and the house itself (see Table 1).

Thus, on balance location is more important than the house, which as such is well known from household surveys. However, here at least three different viewpoints could be distinguished behind these scores. First and foremost, like many other cities, also Budapest was perceived as a fairly segregated city, and the more segregated the city, the more location counts for the buyer's choice. Second, one respondent emphasized that the area matters only for the first dwelling buyers, and that, when moving upward in the housing career, the quality of the house matters much more than the location. Finally, at least one interview clearly maintained that, usually both the location and the house are severely deteriorated within this segment and neither of them really matters for the potential buyer or renter.

Table 1. Comparison of the importance: location vs. house

\begin{tabular}{lll}
\hline Respondent & Location & House \\
\hline 1. & 80 & 20 \\
2. & 40 & 60 \\
3. & 50 & 50 \\
4. & 20 & 80 \\
5. & 60 & 40 \\
6. & - & - \\
7. & 60 & 40 \\
8. & 70 & 30 \\
9. & 90 & 10 \\
Ranges & $20 \ldots 90$ & $10 \ldots 80$ \\
Median & 60 & 40 \\
\hline
\end{tabular}




\subsection{AHP elicited profiles for demand side segments}

The idea was to create one aggregate profile and a few more disaggregated profiles based on the elicitation intensities and their variation (see Kauko, 2006, for prior exercises undertaken in Metropolitan Helsinki and the Dutch Randstad). The profiles were aggregated using the Perth -formula $(a+4 b+c) / 6$, where $a$ is the smallest value, $b$ the median and $c$ the largest value of the observations. This way extreme elicitations for $a$ and $c$ do not bias the calculations too much. This is considered a safe way of aggregating the profiles.

The aggregate profile is shown in Figure 2. (The disaggregated profiles are obtainable from the author upon request.) Overall, the social factors are the most important and the services the least important attributes.

It can be noted that the accessibility obtains a very low score. The responses may also be divided into four differentiated patterns based on simple grouping of the profiles (see Table 2). In order to make connections with known cases, a number of simple labels were given in order to easily generalise the type of dominating features we are dealing with, according to the principles of naturalistic generalisation already explained.

Four specific profiles were identifiable. A 'more traditional European' urban sentiment (urbanity) emphasises the physical environment (respondents 5 and 9 above). According to respondent 8 the social dimensions are important too, whereas accessibility is not. A

SOCIAL FACTORS
MUNICIPALITY
PHYSICAL ENVIRONMENT
ACCESSIBILITY
SERVICE INFRASTRUCTURE

SOCIAL FACTORS

PHYSICAL ENVIRONMENT

SERVICE INFRASTRUCTURE
, 347

, 234

, 212

, 128

, 079

Figure 2. Aggregate model

Table 2. The respondent profiles as naturalistic generalisations

\begin{tabular}{lll}
\hline Respondent & Most important attribute & Least important attribute \\
\hline 1. & Accessibility (social) & Municipality \\
2. & Social & Services \\
3. & Social & Municipality \\
4. & Social & Services \\
5. & Physical & Services \\
6. & Social & Accessibility \\
7. & Municipality & Services \\
8. & Physical, social & Accessibility \\
9. & Physical & Municipality \\
\hline
\end{tabular}


'more American' segregation sentiment emphasises the social factors (respondents 2, 3, 4 and 6) or the municipality in the sense of a 'Tiebouteffect': the households choose their jurisdiction based on the combination of public expenditures and image - variations in tax rate is however not (yet) reality in Budapest (respondent 7). Finally, when accessibility (and also social) factors are important, the profile is akin to what Kauko (2002, 2003, 2006) found in the Helsinki analysis (respondent 1).

These four general profiles can be elaborated further using the supporting 'in-depth' comments of the nine respondents (almost verbatim from the open interviews when asked about the logic of a certain ranking):

'Traditional urban' (three respondents).

- All districts include good and bad areas. Closeness to Danube matters. (Tangible factor.)

- To some extent the inner part of district VII is still quite popular as it is a 'historical' area. (Intangible factor.)

- Even if the neighbourhood is not renewed, but it is close to the rehabilitated properties it is attractive. Thus, the anticipation of a change towards the better matters. (Intangible factor.)

- Nice physical environment and not having social problems go together.

'Segregation' (four respondents).

- While the social factors are improving with time, if there are 50\% Romas in a building people do not move there.

- Social factors are important for the upper classes. However, unlike in the US, negative social externalities such as school district or crime rate are irrelevant here. (Thus it is only about status and possibly a 'sense of community'.)

'Tiebout' (one respondent).

- In general, young families look for cheap alternatives in the inner city, and consider districts IX, VII and XIII.
- The social aid is the best in district VIII.

- According to surveys the district (kerület) matters to some extent (when moving in, and also when moving out); its image matters more than its policies.

- Buyers from Budapest and elsewhere are two separate groups: the former group knows better about the district image, and therefore avoids district VIII.

'CBD Accessibility' (one respondent).

- It is important to have good accessibility to downtown and other areas with good services.

- Proximity to education services is important for housing choice in this context; young residents choose a temporary dwelling. (This fits socio-demographic housing theory.)

- Not everyone wants a car and then public transport is important.

- With the increase of private cars parking problems have become worse.

- People do not care about the image of the municipality, if the neighbourhood is acceptable - provided they have all the relevant information.

In sum, the four disaggregated profiles above all follow the aggregate profile with regard to the relative importance of the attributes. Social factors was by far the most important attribute overall. The municipality factor, the physical environment and the services were all considered less important attributes. Accessibility was also played down in many of the interviews, which raises some further thoughts, as having a short travel distance to the city centre in general is considered an important attribute for location choice in the literature on mono-centric Western cities. 


\section{CONCLUSIONS AND DISCUSSION}

Following the principles of naturalistic generalisations, ones case repertoire is allowed to grow, with the purpose of operational classification. Budapest inner city was analysed by classifying its housing consumer profiles into groups, which may be related to earlier studies from other geographic and institutional circumstances and/or to general theory cases from the literature. Based on these findings, two locational factors matter for the preference formation. First, to avoid Roma concentrations this is the same for all movers. This finding is not unlike models of social segregation from the US, where the avoidance of ethnic concentrations is a common finding. The second finding, in turn, reflects traditional European urban sentiments: that is to say, the closeness to the city, and living in the densest possible (but nevertheless pleasant) urban environment is appreciated. This finding is much similar to the findings from other European housing market contexts. However, in the Budapest segment in question this is not an issue of public transport, which is good everywhere, but rather about 'nice architecture', properly urban density and the cityscape. Considering the literature, this is hardly surprising, and by no means a new phenomenon - compare for example with Ley's (1986) findings about a 'prourban ethos' in Canadian cities.

Apparently the condition of the dwelling is not as important as the micro-location, i.e. the condition of the block or the building as a whole. On the other hand, the administrative district (kerület) does not matter that much either, which confirms the prior market based modelling results where the immediate surroundings of the dwelling is considered the key to location choices (see Kauko, 2007). Thus, the most attractive locations are the ones that contain a strong presence of a traditional urban sentiment in the cityscape, or the ones that do not suffer from social dis-amenity influences caused by proximity to ethnic minority concentrations. Besides these attributes, the appropriate area level matters too. That is to say, each target location is considered on a small spatial scale: the building, the block and the immediate vicinity.

An interesting possibility now opens up: we can make a comparison with other studies from a post-communist Eastern European urban context. At least one of the results above raise intriguing thoughts (see Figure 2): CBD accessibility carries less weight than the attributes related to the prestige and environmental attributes of the neighbourhood, and image of the district. Apparently more than a decade of free market has not erased the backwardness of the outer part of the inner city as a residential environment and where a noticeable upgrading has taken place, it will be seen in the expressed choices of housing consumers too. This is potentially a key issue. At least two recent studies on this context corroborate this finding: using regression analysis Raslanas and colleagues (2006) concluded that in Vilnius, Lithuania, CBD accessibility is not an important factor for the price formation of apartments; and using expert judgements, the AHP and a hedonic approach Kryvobokov (2006) found out that in Donetsk, Ukraine the most important value influencing factor is prestige, followed by proximity to positive environmental externalities with scarcity value (in this case parks and water), and only after that by the traditional variable CBD accessibility. That this feature, as a rule, is taken for granted, and therefore neglected, by the residents in Eastern bloc urban context could thus be developed into a testable hypothesis.

Lastly, the methodological findings require some attention. It was noted that the nuanced findings of location specific housing consumption are achieved at the cost of some undoubted and perhaps unavoidable drawbacks, namely 
the lack in modelling robustness, restrictiveness of the analysis, and the effect of averaging the estimates. Obviously these limits are of concern, if the application is in housing market modelling or real estate valuation, and the benchmark is a hedonic regression model or a quantitative stated preferences model. On the other hand, we may argue against treating the expert elicited AHP approach as a completely quantitative method. After all, the input data - expert interviews - is judgemental by definition. Besides, triangulation with other methods and datasets will to a great extent help in overcoming problems of reliability and validity. Cautiously considered, the real merit of this analysis may be in generating preliminary or confirmatory findings in an environment where little comparable research has been conducted.

\section{Acknowledgement}

An earlier draft of this paper was presented at the $13^{\text {th }}$ conference of the European Real Estate Society (ERES) in Weimar, Germany, June 7-10, 2006. I wish to thank the audience of the session for a stimulating discussion on the topics covered and issues raised.

\section{REFERENCES}

Ball, J. and Srinivasan, V. C. (1994) Using the Analytic Hierarchy Process in house selection. Journal of Real Estate Finance and Economics, 9(1), p. 69-85.

Bender, A., Din, A., Favarger, P., Hoesli, M. and Laakso, J. (1997) An analysis of perceptions concerning the environmental quality of housing in Geneva. Urban Studies, 34(3), p. 503-513.

Bender, A., Din, A., Hoesli, M. and Laakso. J. (1999) Environmental quality perceptions of urban commercial real estate. Journal of Property Investment and Finance, 17(3), p. 280-296.

Bertaud. A. (2006) The spatial structures of Cen- tral and Eastern European cities, In Tsenkova, S. and Nedovic-Budic, Z. (eds), The Urban Mosaic of Post-Socialist Europe, Space, Institutions and Policy, Heidelberg: Physica-Verlag, p. 91110.

Cameron, S. (2006) From low demand to rising aspirations: housing market renewal within regional and neighbourhood regeneration policy. Housing Studies, 21(1), p. 3-16.

Daly, J., Gronow. S., Jenkins, D. and Plimmer, F. (2003) Consumer behaviour in the valuation of residential property. A comparative study in the UK, Ireland and Australia. Property Management, 21(5), p. 295-314.

Di Clemente, D. F. and Hantula, D. A. (2003) Applied behavioural economics and consumer choice. Journal of Economic Psychology, 24(5) October, p. 589-602.

Egedy, T. (2000) The situation of high-rise housing estates in Hungary, In Kovács, Z. (ed.), Hungary towards the 21 $1^{\text {st }}$ Century: the human geography of transition, Studies in Geography in Hungary 31, Geographical Research Institute, Hungarian Academy of Sciences, Budapest, p. 169-185.

Egedy, T. (2001) Budapest pilot study - Havanna housing estate, In Kovács, Z (ed.), Housing policy and social exclusion, Nehom - Neighbourhood Housing Models, Project under the EU $5^{\text {th }}$ Framework Programme: 'Improving the quality of life', D2, Department of Geography, University of Bergen, p. 15-34.

Erkut, E. and Moran, S. R. (1991) Locating obnoxious facilities in the public sector: an application of the Analytic Hierarchy Process to municipal landfill siting decisions. Socio-economic planning sciences, 25(2), p. 89-102.

Galster, G. (2001) On the nature of neighbourhood. Urban Studies, 38(12), p. 2111-2124.

Gregory, R. (2000) Valuing environmental policy options: a case study comparison of multiattribute and contingent valuation survey methods. Land Economics, 76(2), p. 151-173.

Gregory, R., Flynn, J., Johnson, S. M., Satterfield, T. A., Slovic, P. and Wagner, R. (1997) Decision-pathway surveys: a tool for resource managers. Land Economics, 73(2), p. 240-254.

Grigsby, W., Baratz, M., Galster, G. and Maclennan, 
D. (1987) The dynamics of neighbourhood change and decline. Progress in Planning, 28 (1), p. 1-76.

Guerin, B. (2003) Putting a radical socialness into consumer behaviour analysis. Journal of Economic Psychology, 24(5) October, p. 697-718.

Johansson, R. (2005) On case study methodology, In Vestbro, D.U., Hürol, Y., and Wilkinson, N. (eds.), Methodologies in housing research, Gateshead: Urban International Press, p. 3039.

Kaklauskas, A., Zavadskas, E.K., Banaitis, A. and Šatkauskas, G. (2007) Defining the utility and market value of a real estate: a multiple criteria approach. International Journal of Strategic Property Management, 11(2), p. 107-120.

Kauko, T. (2002) Modelling locational determinants of house prices: neural network and value tree approaches doctoral dissertation, University of Utrecht, http://www.library.uu.nl/decollectie/ proefschriften/11688main.html

Kauko, T. (2003) Residential property value and locational externalities: on the complementarity and substitutability of approaches. Journal of Property Investment \& Finance, 21(3), p. 250270.

Kauko, T. (2004) Sign value, topophilia and the locational component in property prices. Environment and Planning A, 36(5), p. 859-878.

Kauko, T. (2006) What makes a location attractive for the housing consumer? Preliminary findings from metropolitan Helsinki and Randstad Holland using the analytical hierarchy process. Journal of Housing and the Built Environment, 21, p. 159-176.

Kauko, T. (2007) A heterodox economic analysis of the housing market structure in Budapest using neural network classification. Journal of Real Estate Literature, 15(1), p. 85-124.

Kok, H. and Kovács, Z. (1999) The process of suburbanization in the agglomeration of $\mathrm{Bu}-$ dapest. Netherlands Journal of Housing and the Built Environment, 14(2), p. 119-141.

Kovács, Z. (1994) A city at the crossroads: social and economic transformation in Budapest. $U r$ ban Studies, 31(7), p. 1081-1096.
Kovács, Z. (1997) Aspects of Post-Socialist Transformation in Eastern Europe with Special Attention to the Labor and Housing Market, In van Weesep, J. (ed.), Conference proceedings, 'Transformation Processes in Eastern Europe', Part I, Housing and the Labor Market, March 6 and 7, 1997, ESR, The Hague, p. 43-56.

Kovács, Z. (1998) Ghettoization or gentrification? Post-socialist scenarios for Budapest. Netherlands Journal of Housing and the Built Environment, 13(1), p. 63-82.

Kovács, Z. and Douglas, M. (2004) Hungary, From socialist ideology to market reality, In Turkington, R., van Kempen, R. and Wassenberg, F. (eds.), High-rise housing in Europe, Current trends and future prospects, Housing and urban policy studies 28, Delft: DUP Science, p. 231-248.

Kovács, Z. and Székely, J. (2004) Hungarian Housing Policy Before and After Transition, In Kovács, Z. (ed.), Housing policy and social exclusion, Nehom - Neighbourhood Housing Models, Project under the EU $5^{\text {th }}$ Framework Programme: 'Improving the quality of life', D2, Department of Geography, University of Bergen, p. 128-139.

Kovács, Z. and Wiessner, R. (2004) Budapest - Restructuring a European Metropolis. Europa Regional, 12(1), p. 22-31.

Kryvobokov, M. (2005) Estimating the weights of location attributes with the analytic hierarchy process in Donetsk, Ukraine. Nordic Journal of Surveying and Real Estate Research, 2(2), p. 5-29.

Kryvobokov, M. (2006) Mass valuation of urban land in Ukraine: from normative to a market-based approach, Doctoral thesis in Real Estate Planning, Real Estate Planning and Land Law, Department of Real Estate and Construction Management, School of Architecture and the Built Environment, Royal Institute of Technology (KTH), Stockholm.

Ladányi, J. (1989) Changing patterns of residential segregation in Budapest. International Journal of Urban and Regional Research, 13(4), p. 555-572.

Ley, D. (1986) Alternative explanations for innercity gentrification: a Canadian assessment. 
Annals of the Association of American Geographers, 76(4), p. 521-535.

Locsmándi, G. (2006) National report - Hungary and Budapest.

McLean, D. G. and Mundy, B. (1998) The addition of contingent valuation and conjoint analysis to the required body of knowledge for the estimation of environmental damages to real property. Journal of Real Estate Practice and Education, 1(1), p. 1-19.

Maclennan, D. (1977) Some thoughts on the nature and purpose of house price studies. Urban Studies, 14, p. 59-71.

Molin, E., Oppewal, H. H. and Timmermans, H. (1999) Group-based versus individual-based conjoint preference models of residential preferences: a comparative test. Environment and Planning A, 31, p. 1935-1947.

Nevalainen, R., Staffans, A. and Vuorela, P. (1990) Asumisen laadun arviointi ja tutkiminen (Evaluating and studying the quality of housing, in Finnish), Center for Urban and Regional Research (YTK), Helsinki University of Technology, Helsinki.

Ong, S. E. and Chew, T. I. (1996) Singapore residential market: an expert judgemental forecast incorporating the analytical hierarchy process. Journal of Property Valuation \& Investment, 14(1), p. 50-66.

Pöyhönen, M. (1998) On Attribute Weighting in Value Trees, Systems Analysis Laboratory Helsinki University of Technology, Helsinki.

Raslanas, S., Tupenaite, L. and Steinbergas, T. (2006) Research on the prices of flats in the South East London and Vilnius. International Journal of Strategic Property $M a$ nagement, 10(1), p. 51-63.

Rév8 (2004) Józsefváros 15 éves kerületfejlesztési stratégia (15 years district development strategy, in Hungarian), September.
Rietveld, P. and Wagtendonk, A. J. (2004) The location of new residential areas and the preservation of open space: experiences in the Netherlands. Environment and Planning A, 36, p. 2047-2063.

Rothenberg, J., Galster, G., Butler, R. and Pitkin, J. (1991) The maze of urban housing markets: theory, evidence and policy. University of Chicago Press, Chicago.

Saaty, T. L. (1990) How to make a decision: the Analytic Hierarchy Process. European Journal of Operational Research, 48, p. 9-26.

Strand, J. and Vågnes, M. (2001) The relationship between property values and railroad proximity: a study based on hedonic prices and real estate brokers' appraisals. Transportation, 28, p. 137-156.

Tosics, I. (2006) Spatial restructuring in post-socialist Budapest, In Tsenkova, S. and NedovicBudic, Z. (eds), The Urban Mosaic of Post-Socialist Europe, Space, Institutions and Policy, Heidelberg: Physica-Verlag, p. 131-150.

Wang, D. and Li, S.-M. (2004) Housing preferences in a transitional housing system: the case of Beijing, China. Environment and Planning A, 36 , p. $69-87$.

Whitehead, C. M. E. (1999) Urban housing markets: theory and policy, in Mills, E. S. and P. Cheshire (eds.), Handbook of Regional and Urban Economics. Elsevier Science BV. p. 1559-1594.

Willis, K. G. and Garrod, G. D. (1993) Not from experience: a comparison of experts opinions and hedonic price estimates of the incremental value of property attributable to an environmental feature. Journal of Property Research, 10, p. 193-216.

Zahedi, F. (1986) The Analytic Hierarchy Process a survey of the method and its applications. Interfaces, 16(4) July-August, p. 96-108. 


\section{SANTRAUKA}

EKSPERTŲ VERTINIMAIS PAGRİSTA BŪSTO APLINKOS POŽYMIŲ ANALIZĖ BUDAPEŠTO (VENGRIJA) CENTRE

\section{Tom KAUKO}

Vykdant tyrimus svarbus uždavinys - įvertinti aplinkos kokybės vaidmenį renkantis būstą, nepamirštant su paklausa susijusių aplinkybių, kurias lemia ekonominiai ir socialiniai bei kultūriniai pokyčiai miestų ir didmiesčiu būsto rinkose. Kai paklausa yra įvairi, vartojimo polinkiai suformuoja skirtingų pageidaujamų savybių komplektą. Praktine prasme tokius rezultatus galima gauti įvertinus aplinkos požymius pagal santykinę jų svarbą namo pirkejjui arba nuomininkui. Pavyzdžiui, šią procedūrą galima atlikti lyginant požymių poras pagal ekspertų vertinimus ir taikant analitinị hierarchinị procesą (AHP). Šis tyrimas pagrịstas ekspertų sudarytais gyvenamosios vietos kokybès aprašymais Budapešto centre ir remiasi ankstesniais būsto rinkos analizès darbais. Šiame darbe dėmesys atkreipiamas ị vieną problemą, būdingą pokomunistinėms šalims - siūlomų produktų grupių asortimentas neatitinka pirkejjo pageidavimų. Pirkejjai vis dažniau akcentuoja kokybę ir diferencijuoja savo poreikius. 